University of Nebraska - Lincoln

DigitalCommons@University of Nebraska - Lincoln

2016

Support for Drought Response and Community Preparedness:

Filling the Gaps between Plans and Action

Kelly Helm Smith

Crystal J. Stiles

Michael Hayes

Christopher Carparelli

Follow this and additional works at: https://digitalcommons.unl.edu/hprccpubs

Part of the Atmospheric Sciences Commons, Climate Commons, Environmental Indicators and Impact Assessment Commons, Environmental Monitoring Commons, Fresh Water Studies Commons, Hydrology Commons, Meteorology Commons, Natural Resources Management and Policy Commons, Sustainability Commons, and the Water Resource Management Commons

This Article is brought to you for free and open access by the High Plains Regional Climate Center at DigitalCommons@University of Nebraska - Lincoln. It has been accepted for inclusion in HPRCC Personnel Publications by an authorized administrator of DigitalCommons@University of Nebraska - Lincoln. 


\title{
Support for Drought Response and Community Preparedness: Filling the Gaps between Plans and Action
}

\author{
Kelly Helm Smith, Crystal J. Stiles, \\ Michael J. Hayes, and Christopher J. Carparelli
}

Kelly Helm Smith is the communication and planning specialist at the National Drought Mitigation Center, based at the University of NebraskaLincoln. Smith is particularly interested in ways to connect drought planning with other planning processes.

Crystal J. Stiles is an applied climatologist with the High Plains Regional Climate Center, located at the University of Nebraska- Lincoln.

Michael J. Hayes is the director for the National Drought Mitigation Center (NDMC) located within the School of Natural Resources at the University of Nebraska-Lincoln.

Christopher J. Carparelli is a Big Sky Watershed Corps member with the Beaverhead Watershed Committee in Dillon, Montana.

\begin{abstract}
This chapter examines which levels of government handle various aspects of drought, as well as interactions between levels of government, providing examples from states across the western United States. It also takes a look at aspects of drought that fall outside traditional lines of authority and disciplinary boundaries. As part of a discussion on how states support local drought response, the chapter details and contrasts how California and Colorado track public water supply restrictions, and describes Colorado's process for incorporating input from river basins across the state into its water plan. Case studies focus on drought planning in the Klamath River and Upper Colorado River basins through the lens of collaborative environmental planning. The chapter concludes that drought planning will be more effective as more states coordinate and align goals and policies at multiple levels of government.
\end{abstract}

Published as Chapter 7 in Water Policy and Planning in a Variable and Changing Climate: Insights from the Western United States, edited by Kathleen A. Miller, Alan F. Hamlet, Douglas S. Kenney, \& Kelly T. Redmond. CRC Press, Taylor \& Francis Group, 2016.

Copyright (c) 2016 by Taylor \& Francis Group, LLC. Used by permission. 


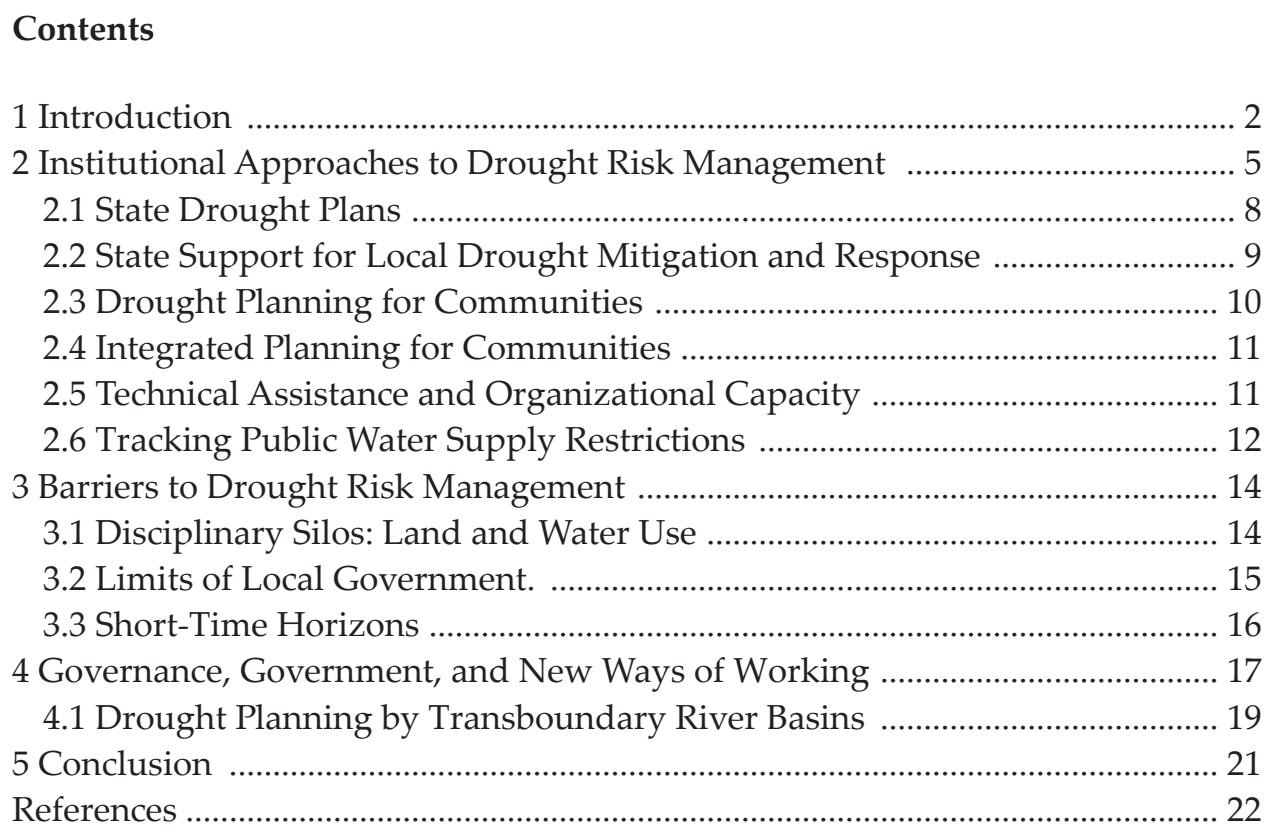

\section{Introduction}

Flying over a landscape reveals patterns of land use that are not visible from ground level. You may notice a patchwork of crops, with the rows and leaf textures of a field showing up as distinct shades of green, or circles of crops under center-pivot irrigation, indicating availability of groundwater. Farther west, bare, arid ground gives way to riparian strips of irrigated, cultivated land. Rivers and mountains form natural boundaries, but state borders are indistinguishable. The difference in perspective between $30,000 \mathrm{ft}$. and ground level is also true for socioeconomic systems. The pressures and opportunities for conservation, development, and sustainable resource use look very different, depending on whether you're sitting in a small-town mayor's office, a regional planning office, a tribal council, or the state capital. Although the most local levels of government may have the fewest resources and the least ability to gain a big-picture perspective higher than the town water tower, traditionally municipal matters such as zoning and water supply decisions may have some of the greatest effects on patterns of water use and drought resilience. Fortunately, just as technology now makes it possible for people to view the planet as if from space in one instant and to zoom down to their own backyard in the next, an increasing array of collaborative methods is evolving 
to support working across and between traditional lines of authority and levels of jurisdiction. This chapter will provide an overview of recent developments in drought planning that ensure that decision makers at state, tribal, municipal, and other levels of authority are working within a consistent understanding of opportunities and constraints. Failing to share data and create a shared perspective may result in decision making based on short-term economic interests that diminish drought resilience for an entire watershed.

Droughts are a normal part of the climate across the western United States and thus have had a tremendous influence on both the cultures and the environments across the region, most recently in 2011-2015. In 2011, a very intense drought combined with record heat struck the southern Plains. The 2012 drought was more widespread and affected large parts of the United States, including regions outside the West. Drought conditions and the associated dust storms in early 2014 revived images of the Dust Bowl in the southern High Plains. Meanwhile, very intense drought was entrenched in California and adjacent states in 2014-2015. The resulting impacts have occurred within agriculture (both to crops and livestock), affected drinking water supplies in both rural and urban areas, enhanced wildfire potentials, and created challenging wildlife management issues. According to the National Climatic Data Center's list of billion-dollar weather disasters, drought cost the United States $\$ 4$ billion in 2014, $\$ 10$ billion in 2013, $\$ 30$ billion in 2012, and $\$ 12$ billion in 2011 (NCDC 2015). The University of California-Davis estimated that drought in 2014 would cost the state $\$ 1$ billion in agricultural revenue and $\$ 0.5$ billion in additional pumping costs, with a total statewide economic cost of $\$ 2.2$ billion, and a loss of 17,100 seasonal and part-time agricultural jobs (Howitt et al. 2014).

These recent drought examples in the western United States occurred amid growing concerns from scientists and officials about food security, water shortages, energy supplies, climate change, and the complex interactions of these issues. The recent National Climate Assessment report highlights the southwestern United States as a region facing future increases in both drought frequency and intensity (Garfin et al. 2014). Trying to anticipate future drought impacts in the western United States requires an understanding of the past, as well as an understanding that the past may not represent the best analog for the future given the changing climate and shifting vulnerabilities 
across the region (Milly et al. 2008). New challenges loom-growing populations place increasing demands on limited water resources, and elevated temperatures compound the effects of low precipitation, a phenomenon that Overpeck (2013) calls "hot droughts."

The issue of drought in the West fits well into a larger context pointed out within a 2013 United Nations report. In that report, it was estimated that the direct losses from natural disasters globally since 2000 are potentially in the US $\$ 2.5$ trillion range (UNISDR 2013). Natural disasters such as drought will be significant issues for all societies in the future. In a press release accompanying the report, UN Secretary-General Ban Ki-moon argued that the "economic losses from disasters are out of control" and that these losses will continue to escalate unless actions are taken to reduce disaster risks in the future. In the western United States and other regions with a projected increase in drought under a changing climate, it is critical that we understand how to reduce vulnerability and that we act on that knowledge.

Social planners Rittel and Webber in 1973 coined the term "wicked problems" to refer to complex problems that are difficult to define; involve complex sets of actors, issues, and trade-offs; and are impossible to isolate in laboratory conditions. Botterill and Cockfield (2013) observe that planning for drought is wicked in the following ways:

- There is no definitive formulation of the problem.

- The problems have no stopping rule.

- Solutions are not true or false, but rather, bad or good.

- Every solution is a "one-shot" operation; because there is no opportunity to learn by trial and error, every attempt counts significantly (Botterill and Cockfield 2013, pp. 9-10).

Adding to the complexity of drought planning is that no single discipline, profession, or sector has a monopoly on defining, experiencing, and managing drought. Agricultural policy and practices, laws governing water management and delivery, and urban and environmental land-use policies each affect our collective vulnerability to drought yet may often evolve in parallel, nonintersecting contexts. Much agricultural policy comes from the federal government. States are the primary level of authority for enacting laws governing water. Many land-use decisions that affect water consumption, runoff, 
or absorption happen in local offices that are typically separate from the utilities that actually deliver water to households.

One more good reason to plan for drought is that it is a good starting point and capacity-building exercise in planning for a changing climate. Both involve a slow-moving phenomenon that is difficult to detect until it is already well underway. Planning for both drought and climate change requires processes that involve many sets of stakeholders with different interests who are interested in and respond to different kinds of information and data. Both also involve a shift of perspective, from planning what to do in case of emergency (response) to planning to avoid an emergency (hazard mitigation, climate adaptation).

\section{Institutional Approaches to Drought Risk Management}

Traditionally, most of the efforts focusing on drought impacts have dealt with responding to these impacts after an event. Beginning in the 1970s and 1980s, scientific and policy organizations described ad hoc responses to drought as uncoordinated and untimely (GAO 1979; Wilhite and Pulwarty 2005; GSA 2007) and began calling for better coordination of government responses to drought (Wilhite 1991). The alternative to treating every drought as a separate, unforeseeable emergency is to emphasize improving drought monitoring, planning, and mitigation strategies to reduce impacts from future droughts (Wilhite et al. 2005). This approach is in accord with the shift in focus from disaster response to disaster risk reduction that was officially recognized when the United Nationals General Assembly declared the 1990s the International Decade for Disaster Risk Reduction (Hellmuth et al. 2011). This approach requires identifying who and what are at risk, why they are at risk, how individuals or organizations respond to events, and what steps can be taken ahead of time to reduce risk. Underscoring a shift toward anticipating droughts as a recurrent feature of climate, the National Drought Policy Commission (NDPC) in 2000 recommended favoring "preparedness over insurance, insurance over relief, and incentives over regulation" (National Drought Policy Commission 2000, p. 35). The NDPC also recommended passing a national drought preparedness act and creating a national drought council to coordinate national drought policy in the United States 
(National Drought Policy Commission, cited in Whitney 2013, pp. 7374). As of 2014, the broader recommendations for a comprehensive US drought policy had not been enacted, but monitoring and early warning provisions had been implemented.

In 2006, Congress established the National Integrated Drought Information System (NIDIS), to consolidate the nation's drought early warning and monitoring capabilities, with the National Oceanic and Atmospheric Administration (NOAA) as the lead agency. Through its website (http://www.drought.gov), NIDIS provides one-stop access to drought monitoring products from many federal agencies, including NOAA, the US Department of Agriculture (USDA), the National Aeronautics and Space Administration (NASA), the US Geological Survey, and more. Most recently, the National Drought Resilience Partnership, introduced in 2013 as part of President Barack Obama's Climate Action Plan, calls for the development of long-term planning and resilience strategies to improve the nation's drought preparedness (Bergman 2014; NIDIS 2014), with the USDA as the lead agency. The USDA is also the agency most active in providing drought relief to agricultural producers, particularly through crop insurance.

As a slow-moving hazard, drought falls outside the traditional emergency management responses to natural disasters, as set forth in the Stafford Act of 1988 and amended by the Disaster Mitigation Act of 2000. The purpose of the Stafford Act is "to reduce the loss of life and property, human suffering, economic disruption, and disaster assistance costs resulting from natural disasters" (FEMA 2013, pp. $1-2)$, and it specifically includes drought in a list of major disasters. However, the Federal Emergency Management Agency (FEMA) has not typically been involved in official federal responses to drought, nor has the Stafford Act been invoked specifically for drought within the continental United States. Although drought may be as cumulatively disruptive as faster-moving disasters, legal and environmental scholar Jeremy Brown describes it as lacking charisma or screen presence. He notes that if FEMA or others responded to drought under the Stafford Act, it would permit additional benefits including unemployment, supplemental nutrition assistance (formerly food stamps), and crisis counseling (Brown 2014).

The Disaster Mitigation Act of 2000 emphasizes state and local mitigation planning, noting that "high priority should be given to mitigation of hazards at the local level" (Section 101[4]). Multihazard 
mitigation plans are a prerequisite for local governments to access various FEMA mitigation grants. Although drought is not one of the handful of disasters specifically named in the Disaster Mitigation Act of 2000, emergency and hazard mitigation planners can include drought mitigation in multihazard mitigation plans. Many of the strategies that reduce vulnerability to drought also reduce vulnerability to other hazards.

States, which have the legal authority to regulate water, have been more active in implementing drought plans. In the aftermath of the late 1970s drought, Don Wilhite, a professor at the University of Nebraska-Lincoln, began investigating what drought risk management would look like in context of state drought planning efforts. Wilhite's first efforts were to work with states on the concept of drought planning, and he first codified states' approaches to drought planning in 1990 as the 10-Step Drought Planning Process. He has been helping disseminate the fundamentals of drought planning since then. The 10 steps that Wilhite identified, and that have been adapted by states, tribes, and countries around the world, are as follows:

1. Appoint a drought task force.

2. State the purpose and objectives of the drought plan.

3. Seek stakeholder participation and resolve conflict.

4. Inventory resources and identify groups at risk.

5 . Establish and write the drought plan.

6. Identify research needs and fill institutional gaps.

Integrate science and policy.

8. Publicize the drought plan.

9. Develop educational programs.

10. Evaluate and revise the drought plan (Wilhite et al. 2005, pp. 93-94).

Wilhite worked with the USDA and NOAA to establish the National Drought Mitigation Center (NDMC) in 1995 at the University of Nebraska-Lincoln. The center's mission is to reduce societal vulnerability to drought. One of the NDMC's main emphases has been fostering drought planning, and the center has done so at scales from the individual farm or ranch to communities, tribes, river basins, states, and countries around the world. In 1995, 27 states had drought plans. As of 2014, 45 states had drought plans, according to 
the NDMC's ongoing collection and catalog of plans on its website ( http://drought.unl.edu/Planning/PlanningInfobyState.aspx ).

\subsection{State Drought Plans}

A recent assessment of drought plans from all 19 Western Governors' Association states identified several common themes. Typical state drought response strategies include increasing communication, issuing water restrictions, facilitating and/or expediting water transfers or temporary permits, purchasing water rights to keep water in streams, financial support for public water suppliers, recommending measures such as permitting roadside haying, and activating state assistance and technical support (Fontaine et al. 2014). State officials identified the following as mitigation strategies, which are implemented proactively to reduce drought vulnerability: increasing water conservation, especially for development and growth; enhancing water supplies; improving delivery infrastructure and intersystem connections; increasing availability of monitoring data; promoting rangeland fire insurance; and requiring public water systems (PWSs) to address drought in their planning documents. Many states' drought communication processes include opportunities for input from different localities and sectors.

Some states have established local groups that provide information to the state on drought conditions and impacts, enabling the states to focus response efforts. Other state monitoring groups use field agents to report on local impacts. Many state drought committees have individual state agencies that report on drought-impact information from specific sectors, and then provide assistance as needed.... (Fontaine et al. 2014, p. 97)

Asked to identify factors contributing to a successful drought program, state drought coordinators highlighted the need for communication and coordination with local entities, including encouraging local governments to develop their own drought plans (Fontaine et al. 2014). States take a variety of approaches to fostering drought planning by local entities, including delegating authority to regional or municipal entities and providing technical assistance, data, and model plans. 


\subsection{State Support for Local Drought Mitigation and Response}

Some states work with municipalities or water suppliers to provide resources that improve response to and mitigation of drought. For example, the Colorado Water Conservation Board (CWCB) has developed the Drought Tool Box ( $\underline{h t t p: / / c w c b . s t a t e . c o . u s / t e c h n i c a l-r e-~}$ sources/drought-planning-toolbox/Pages/main.aspx ), a resource that includes discussion of and links to drought monitoring resources, a granting program to help municipal water providers develop drought management plans, drought planning guidance for municipalities, and background information on climate change and drought. The town of Firestone, Colorado, used the Tool Box and worked with a consultant to complete a drought management plan in 2012 (http:// www.firestoneco.gov/DocumentCenter/View/72). (Also see the discussion in this chapter on Colorado's basin-level planning.)

In California, water suppliers over a certain size must file an Urban Water Management Plan every 5 years detailing how they will maintain reliable water supplies under different conditions, which is part of the state's Integrated Regional Water Management planning. Water suppliers must also file water shortage contingency plans. Passage of the Urban Water Management Planning Act of 2001 linked wateruse and land-use planning, making approval of new developments contingent on adequate water supplies (Brislawn et al. 2013). The Department of Water Resources worked with the California Urban Water Coalition and others to produce the Urban Drought Guidebook in 2008.

A succession of dry years in California beginning in 2012 and continuing as of this writing in 2015 led to heightened awareness of the drought risk that California faces. Drought reduced agricultural production, led to mandatory reductions in urban water uses, made it harder for wildlife to find food and water, and revealed the vulnerability of some rural residents, who were confronting dry wells. In 2013, California began holding workshops for rural water providers to increase awareness of the issues likely to arise and actions they could take if drought continued (Weiser 2013). When Governor Jerry Brown proclaimed a drought State of Emergency in January 2014, he was flanked by several department heads, including the leaders of Cal Fire, the Department of Food and Agriculture, the Department of Water Resources, the Water Resources Control Board, and the Governor's Office of Emergency Services (California 2014). The Office of 
Emergency Services played a key role, with its Incident Command System providing a coordinating structure for the interagency effort, and allowing the state to tap into funds under the California Disaster Assistance Act to help address problems such as dry domestic wells (Davis-Franco 2014). In 2014, the California Governor's Office of Planning and Research created the Local Government Drought Toolkit and Local Drought Clearinghouse (http://www.opr.ca.gov/s droughtresources.php) to support local agencies in coping with drought. As part of the January 2014 drought emergency proclamation, Governor Brown called for Californians to reduce water consumption by $20 \%$. Some communities responded much more actively than others, but a state survey found that in May, usage increased by $1 \%$ statewide (Lovett 2014). In midsummer, the State Water Resources Control Board imposed emergency conservation regulations, banning outdoor uses of potable water, such as car washing and non-recirculating fountains, and requiring water suppliers to impose restrictions on outdoor irrigation and to report on water use each month. In November 2014, voters approved Proposition 1, allocating $\$ 7.5$ billion for infrastructure and environmental projects. In early 2015, the drought had further intensified, prompting the governor to issue mandatory water conservation targets for urban water utilities (State of California, Executive Department, 2015).

\subsection{Drought Planning for Communities}

In 2010, the NDMC and partners published the Guide to Community Drought Preparedness, which expresses the core elements of drought planning in a way that may make sense for smaller communities. The guide includes work sheets and many ideas that may contribute to a community's drought planning process, and communities are encouraged to select the pieces that seem most appropriate for the issues that they are facing. The guide deliberately refers to community, a looser term than municipality, anticipating the need for intergovernmental, transboundary processes. A logical drought planning entity in many towns and cities is the public water utility, but water utilities generally have a fairly specific mission related to delivering a continuous supply of drinkable water, and drought may have broader impacts than that. It may make sense to address drought planning at 
the watershed level, uniting agricultural areas and small towns. The guide simplifies the 10-step process, focusing on establishing the planning team and connecting with stakeholders, establishing monitoring, understanding the community's drought history and vulnerability, establishing a public education and outreach program, and identifying and implementing steps to reduce vulnerability to drought (Svoboda et al. 2011).

\subsection{Integrated Planning for Communities}

Many states, tribes, and cities have the resources to conduct standalone drought planning processes. With an understanding of policies and processes that contribute to drought resilience, it is also possible to incorporate elements of drought planning into other planning processes. More entities are beginning to include drought in multihazard planning processes. Integrating mitigation measures for drought and other hazards into other kinds of plans increases the likelihood of reducing drought vulnerability.

The American Planning Association published Planning \& Drought in 2013, a Planning Advisory Service report that introduced concepts of drought planning to urban planners, developed in collaboration with the NDMC and NIDIS. Authors of the chapter on how planners can address drought emphasize that "establishing a fully integrated framework merging land-use and water resource management planning at a regional level might be considered the 'gold standard' in terms of facing the challenges of drought and climate change" (Brislawn et al. 2013, p. 40).

Opportunities to mainstream drought planning include wrapping it into multihazard planning, zoning, comprehensive planning, infrastructure planning, water supply management, storm water and water treatment planning, climate adaptation planning, capital improvement planning, riparian and floodplain planning, conservation planning, watershed protection planning, and more. In short, there is no end of opportunities to incorporate elements that increase resilience to drought into other kinds of planning and practice. The challenge is creating awareness so that planners and decision makers can recognize and act on opportunities as they arise. 


\subsection{Technical Assistance and Organizational Capacity}

Inventorying data and involving data providers are main steps in drought planning, and one of the key ways that state and federal agencies can support community drought planning is by providing data on water, climate, agriculture, and the environment. NIDIS' 2006 congressional mandate includes providing data and drought early warning information to decision makers at all levels, including local government (NIDIS 2007). NIDIS has identified several pilot areas as Regional Drought Early Warning Systems (RDEWS), which aim to develop partnerships between agencies at multiple levels to identify drought risk reduction strategies through monitoring and prediction. These pilot projects also focus on delivering timely, spatially relevant information to test regions across the country.

Agencies can contribute to planning efforts by providing technical services such as geographic information systems (GIS) or by sharing communication capacity to coordinate activities; organize meetings; and distribute agendas, findings, and other information. Research by Floress et al. (2011) found that watershed management groups that included more agency personnel participating as part of their job responsibilities were more effective and better networked than allvolunteer groups.

\subsection{Tracking Public Water Supply Restrictions}

California and Colorado are among the handful of states that have online systems for tracking local PWSs that have imposed either voluntary or mandatory water-use restrictions on customers, although Colorado's system is maintained by the state and California's system is maintained by an industry association. These systems may serve several purposes, including increasing awareness of water supply conditions; helping people figure out what, if any, restrictions apply in their area; and helping government agencies target assistance more effectively. Examples from Colorado and California, described here, illustrate differences in how much effort statewide agencies or organizations have chosen to invest in verifying information from PWSs. Colorado's system, which is a permanent fixture, links users to their PWS for the most recent information. California's system, operational 
only under serious drought conditions, relies on organization staff to find and verify information from PWSs.

The CWCB launched its website http://www.coh2o.co in the spring of 2013 in response to severe drought conditions that had been affecting large portions of the state since 2012. The website offers a search feature that allows users to search water restrictions by entering a city, county, or zip code. Users are then redirected to the web page of the PWS that serves the area they entered. The CWCB saw a need to create the website because there was confusion among the public as to what the specific water-use restrictions were for each area. The Denver metropolitan area is home to several different water providers with service area boundaries that are not common knowledge to the public. Furthermore, the mainstream media coverage in the state is largely focused on the Denver metro area, so Denver-based television news stations or newspapers often do not report droughtrelated PWS water-use restriction information for other communities throughout the state. The CWCB wanted to ensure that the state would not infringe upon local control over water-use restriction information and messaging, so it chose to redirect users to PWS websites rather than collect the information from PWSs for dissemination by the state. The CWCB contacted most of the PWSs in the state and offered them the opportunity to opt into voluntary participation with the website (http://www. coh2o.co). Not all PWSs opted in, and as a result, some website users are affected by these information gaps (Taryn Finnessey, drought and climate change technical specialist, CWCB, Colorado Department of Natural Resources, in discussion with Chris Carparelli, November 12, 2013).

The Association of California Water Agencies (ACWA) is an industry group that represents the interests of 440 PWSs that deliver water to roughly $90 \%$ of California's population. In January 2014, ACWA began posting a map of PWS water-use restrictions on its website (http://www.acwa.com/content/drought-map) in response to escalating drought conditions that began in 2013. The map uses a Google Maps interface with color-coded dots that, when clicked upon, convey local water-use restriction information at that location. ACWA only posts the map during serious drought conditions. Information for the map is collected in a variety of ways. ACWA staff monitor the news, contact member agencies by phone and e-mail, and then update 
the map based on the information gathered. Some member PWSs will also proactively contact ACWA to submit information. The frequency of information collection and map updates is variable, and it is voluntary for PWSs to provide information. The primary purpose of the map is to publicize the impacts of the drought to create public awareness. Member agencies use it to communicate with their customers, and other entities, including the California Department of Water Resources, have embedded the map or provided links to it on their websites. ACWA chose not to design an information collection system that would put the onus on PWSs to provide and maintain data, because it felt that the information would be more accurate if ACWA was the keeper of the information (Matt Williams, communications specialist, ACWA, in conversation with Chris Carparelli, February 12, 2014).

\section{Barriers to Drought Risk Management}

As planners and other resource managers look for opportunities to increase resilience to drought, they should be aware of some pitfalls. As a slow-moving natural hazard, drought tends to be off the radar screen of many people, especially those living in cities, where water and food supplies are more mediated by technology that buffers the population from natural variation. The separation of systems that have evolved to govern and manage water supplies, land use, and food needs to be addressed directly in dealing with drought.

\subsection{Disciplinary Silos: Land and Water Use}

A major challenge for drought resilience is that planning for water supply and for urban land use is traditionally handled by different departments and different professions, and much agricultural decision making happens separately from both of these. Within the boundaries of an incorporated municipality, land-use practices can have a big effect on the demand for water, but water suppliers and city planning and zoning departments are traditionally separate decision-making entities.

In workshops held to update California's Urban Drought Guidebook in 2008, participants identified the following issue: 
The disconnect between planning departments and water suppliers, even within the same city government, continues to stymie efforts to develop new projects with built-in water efficiency and to enforce landscape ordinances. Furthermore, conflicting state and local regulations and policiesespecially those concerning state housing mandates and the ability to serve water, and especially during times of water shortages - need to be addressed. (Schwab 2013, p. 37)

Vivek Shandas, an urban ecologist at Portland State University, and G. Hossein Parandvash, an economist at the Portland Water Bureau, have teamed up to research the gap in land and water planning, and what might be gained by closing it. They note that "the provision of sufficient quantities of water for all forms of development while ensuring adequate supplies for agricultural and nonhuman use is arguably the most significant challenge faced by urban planning agencies" (Shandas and Hossein 2010, p. 112) and that urban planners observed the need to incorporate water into their work as early as 1978, but the administration of water-use and land-use planning have gone the opposite direction since then, becoming increasingly separate. Shandas and Parandvash compared water use at the level of individual parcels of land and found that smaller development size and higher-density single-family residential land use was correlated with lower water use, and they found zoning and development regulations to be key factors in predicting water demand.

\subsection{Limits of Local Government}

The water supply for a farm or for a community may originate some distance away (in some cases, hundreds of miles), which limits the scope of what a single planning entity can accomplish. Many planners' preference is to situate water and drought planning within a regional or landscape-scale effort. Carleton Montgomery, editor of Regional Planning for a Sustainable America, observes, "Regional resources, such as large intact forests and aquifers, are far beyond the power of most municipal governments to conserve, yet development decisions made by local governments represent the greatest threat to these resources" (Montgomery 2011, p. 3). 
Hazard planner Raymond J. Burby also criticized local governments for weighing development interests too favorably:

One of the most serious limitations of the land use approach [to hazard planning] is that without strong mandates from higher-level governments, few local governments are willing to protect against natural hazards by managing development. (Burby 1998, p. 14)

Recognizing the need for a different level of authority, some states have created new entities to govern land and/or water use. In 1980, Arizona's Groundwater Management Act established active management areas (AMAs) to limit groundwater overdraft in and around urban areas. The Assured and Adequate Water Supply program is a key element of the AMAs, ensuring that any new development has enough water and will not exacerbate groundwater depletion. In a review of Arizona's groundwater management policy, Jacobs and Holway (2004, p. 64) stated the following:

In the case of the assured water supply program a strong state-level regulatory approach was essential. The standards for establishing a program like assured supply must be set at a level of government higher than the local governments that have the responsibility to approve or disapprove individual zoning and subdivision proposals.

\subsection{Short-Time Horizons}

Gene Whitney, who worked at the science-policy interface in Washington, DC, for many years, collaborating with both the executive and legislative branches of government, observed the following:

Developing public policy to address the long-term preparedness, mitigation and impacts of drought is difficult in a political culture that increasingly operates with a short-term perspective. In the United States, politicians tend to focus on short-term problems because policies are promulgated by elected officials who operate on...reelection cycles.... [E] ven though recovery may be much more expensive than 
prevention, it is often politically simpler to address an incident after it occurs than it is to prevent an incident or reduce its impact. (Whitney 2013, pp. 72-73)

\section{Governance, Government, and New Ways of Working}

Much of the literature on governing complex human and environmental systems explicitly recognizes that problems will never align neatly with preexisting boundaries, and that working across organizations, both vertically and horizontally, will be necessary. Drought crosses jurisdictional boundaries, and responses are most effective when local, state, and federal plans and policies align. Although this adds complexity, separate entities working together may voluntarily achieve better results than the old command-and-control regulatory approach. In fact, it is this recognition of the opportunity to have more control over the outcome and the opportunity to achieve a more appealing outcome that provides incentives for parties to participate in collaborative processes. Particularly when working outside traditional lines of authority, creating common understanding through dialog among diverse stakeholders is crucial. One of the most important elements in this new way of working is the recognition that good information alone is not enough. It has to be embedded in human experience, mediated by dialog and collaborative learning, to be effective. Although scientists, planners, and many other professions subscribe to the implicit idea that good data and accurate information can resolve issues, research has shown that it takes more than good information to penetrate to the level of changing behavior or policy, and that decision makers are more likely to use knowledge co-created through dialog (Innes 2010). (See Edella Schlager's excellent discussion in Chapter 6 of the pros and cons of decision making across watersheds, scales, and jurisdictions.)

Scholars studying governance of combined social and environmental systems use various composite terms such as adaptive co-management or collaborative adaptive management to describe an approach that combines adaptive management, an ecological concept, with collaborative governance of water systems. They say that adaptive co-management should incorporate (1) polycentric governance, with overlapping functions providing increased resilience; (2) public participation, 
because buy-in comes through understanding created in dialog, and many types of knowledge must be incorporated; (3) willingness to learn from experience or to build from pilot projects; and (4) a bioregional, watershed perspective, either empowered from above or composed of overlapping jurisdictions (Huitema et al. 2009). Or, as summarized by McNutt et al. (2013, p. 152),

Numerous theoretical and empirical studies have shown that effective management of common-pool resources is easier to realize when communities develop social capital through a distributed and dense social network that develops trust and common understanding and stimulates learning and formulation of alternative response options.

One of the first steps in initiating a polycentric, collaborative governance process is to define the boundaries of the problem, if possible. In the case of water management issues, river basins are frequently a logical area. Recognizing that neither the state nor the local level is ideal for many water management tasks, states have created river basin organizations to provide advice and guidance. In 2005, Colorado passed the Colorado Water for the 21st Century Act, creating roundtables for each of eight river basins and the Denver metropolitan area. Their charge was to incorporate state data as well as input from local governments and water suppliers in a process of issue identification and assessment, and make recommendations back to the state. The state released a draft water plan in December 2014 incorporating recommendations from each basin (online: http://www.coloradowaterplan.org ). The plan draws from basin recommendations to address major challenges such as the need to move water from the western to the eastern side of the Continental Divide; diverting water from agricultural to urban use; the need to preserve the environment for fish, wildlife, and recreation; a changing climate; and the need to fund increased water security (Colorado Water Conservation Board 2014).

Water suppliers in many parts of the country are also involved in protecting upstream watersheds. Land management practices that contribute to good water quality, such as maintaining healthy forests, also work to slow runoff and increase infiltration, which increase drought resilience. 


\subsection{Drought Planning by Transboundary River Basins}

One planning method that can be used to address drought planning for river basins is collaborative environmental planning (CEP). CEP emerged as a subdiscipline of planning in the 1990s to address complex environmental issues. Perhaps the most important element of CEP is stakeholder involvement. Stakeholders are people who effect change and also those who are affected by it. CEP is most effective when stakeholders are identified and engaged early in the planning process, they are given full participation and allowed to take ownership of the process, they establish and build trust among one another, and they recognize collaborative learning as their primary goal (Randolph and Bauer 1999). Stakeholders who collaborate would not only formulate a plan to solve an environmental issue, but they would implement the plan and continue to update it, as CEP is an iterative process. CEP can be applied to a wide range of environmental issues, including the management of water resources. CEP is particularly useful for river basin planning because many rivers are transboundary in nature, meaning they cross more than one geopolitical jurisdiction, and that may require coordination of planning activities among several groups.

A recent study looked at how CEP is used for drought planning at the river basin level in the United States (Bergman 2014). The study found 12 basins that are engaged in drought planning to some extent. Interviews that were conducted as part of the study revealed six critical areas in which CEP is beneficial for basin-level drought planning: (1) identifying and engaging key stakeholders; (2) increasing collaboration and coordination among stakeholders; (3) enhancing the quality and quantity of information and data upon which decisions are based; (4) increasing communication among stakeholder groups; (5) developing the planning process into one that ensures implementation and continuous updating of the plan; and (6) enhancing awareness of government and legal matters, such as litigation, that can undermine the planning process. Interview participants were also asked if they thought drought planning was best implemented at the scale of a river basin. Some participants stated that planning for drought at the basin scale was best, especially if it is a transboundary river basin, while other participants said that integrated planning, such as integrating river basin planning with state planning, was ideal. 
Two of the basins found by Bergman (2014) to be engaged in drought planning are in the West: the Klamath River Basin and the Upper Colorado River Basin (UCRB). The Klamath River Basin is shared by Oregon and California and supports several uses, including irrigation, hydroelectric generation, tribal water rights, and habitat for wildlife and endangered species. Issues resulting from these competing uses were amplified by drought in the early 2000s, prompting the development of the Klamath Basin Restoration Agreement (KBRA) in 2010. The goals of the KBRA are to restore habitat for fish species in the basin, ensure a sustainable water supply for the various uses of the river, and resolve disputes that arise between the competing users. One section is dedicated to addressing drought planning and providing an assessment of climate change in the basin. The KBRA recognizes the importance of including stakeholders from both Oregon and California to increase cooperation throughout the basin. According to Bergman (2014), federal authorization of the KBRA has been delayed because of resistance at the congressional level, and as of 2012, the drought-plan portion of the agreement had not been implemented, because basin conditions had not been dry enough to warrant further action. Drought in 2014 led to renewed legislative efforts. Senator Rob Wyden introduced the Klamath Basin Water Recovery and Economic Restoration Act in May, and as of November 2014, the bill was making its way through congressional committees (Klamath Restoration Agreements 2014; Clevenger 2014).

Water resource planning officials are also engaged in drought planning for the UCRB. As defined by the Colorado River Compact of 1922 , the UCRB is the portion of the Colorado River Basin that drains above Lees Ferry and includes part of the states of Arizona, Colorado, New Mexico, Utah, and Wyoming. The UCRB has experienced multiple drought episodes and has generally been in drought since the early 2000s. The UCRB was identified by NIDIS as a pilot area where an RDEWS would be implemented. The Upper Colorado RDEWS has focused on providing local input to the US Drought Monitor, coordinated through the Colorado Climate Center. Weekly drought assessment webinars started in early 2010 and have brought together representatives of federal and state agencies, water conservation districts, and recreation and tourism to discuss current conditions, water supplies, and outlooks. The Colorado Water Availability Task Force, which has overlapping membership, can make use of the information 
from the drought webinars to alert relevant decision makers to emerging drought conditions. The Upper Colorado RDEWS has served as a mechanism for strengthening local input into the US Drought Monitor process, which enhances credibility and legitimacy at federal, state, and local levels (McNutt et al. 2013).

The Colorado River has been highly modified for human use, including the creation of the large reservoirs of Lake Powell and Lake Mead. The combination of ongoing drought, the uncertainty of climate change impacts on the basin, and a rapidly growing population in the Lower Basin has caused concern over the future of water supply of the Colorado River. The US Bureau of Reclamation attempted to address these concerns through the conduct of a water supply and demand study for the entire Colorado River Basin that was completed in 2012 (USBR 2012). The study determined that imbalances between the supply and demand of water in the basin are expected in the future, and a collaborative approach to planning will be needed to address the issue. Collaboration between multiple agencies from each of the basin states will be especially important because of the vastness of the basin.

Drought planning for river basins in the West is becoming more important now than ever because of the rapidly growing population of the region and the uncertainty of how climate change will impact precipitation and temperature patterns in the future. International river basins in the West, such as the Rio Grande and the Columbia River basins, must contend with the additional complexity of coordinating water resource management activities with Mexico and Canada, respectively. Collaboration between agencies and coordination of water resource policies is crucial for managing drought effectively in western river basins.

\section{Conclusion}

Daniel Connell of the Australian National University recently described drought as "a force for truth" for Australia in how they, as a nation, must look at climate change (Connell 2010, slide 10). In other words, a thorough examination of drought could reveal important information on how to address climate change. Because of similarities between Australia and the West, Connell's three main points may provide some insights into the issues identified within this chapter. 
First, Connell emphasized that an analysis of drought risk management is the starting point for a comprehensive institutional analysis, which is necessary in understanding how to deal with climate change. It is a call to action for the West to investigate drought risk management approaches. Second, the stress from droughts highlights both the strengths and weaknesses in how a society deals with longterm threats like climate change. The current and recent droughts in the West provide windows of opportunity to identify these strengths and weaknesses, and to understand the political priorities and underlying cultural values revealed by difficult choices in these situations. Third, for better or worse, societies are likely to manage climate change in the same way they manage drought. Therefore, the intentional drought risk management approaches that are taking place and that need to take place may help us in coming years as we face the larger array of risks posed by climate change.

\section{References}

Bergman, C.J. 2014. Improving Drought Management for Transboundary River Basins in the United States through Collaborative Environmental Planning. PhD diss., University of Nebraska-Lincoln.

Botterill, L.C., and G. Cockfield. 2013. Science, policy and wicked problems. In Drought, Risk Management and Policy, edited by Linda Courtenay Botterill and Geoff Cockfield, 1-14. Boca Raton, Florida: CRC Press.

Brislawn, J., M. Prillwitz, and J.C. Schwab. 2013. Drought: How planners can address the issue. In Planning and Drought, edited by James C. Schwab. Planning Advisory Service Report No. 574. Chicago: American Planning Association.

Brown, J. 2014. Always a Disaster, Never a Presidentially Declared One. Blog post, The Center for Global Energy, International Arbitration and Environmental Law, University of Texas at Austin. July 11. http://www.utexas.edu/law/centers/energy/blog/2014/07/ drought-always-a-disaster-never-a-presidentially-declared-one/

Burby, R.J., ed. 1998. Introduction to Cooperating With Nature: Confronting Natural Hazards With Land- Use Planning for Sustainable Communities. Washington, D.C.: Joseph Henry Press.

California Department of Water Resources. 2008. Urban Drought Guidebook. http://www.water.ca.gov/pubs/planning/urban drought guidebook/urban drought guidebook 2008.pdf

California, State of. 2014. Governor Brown Declares Drought State of Emergency. Press release and proclamation. Jan. 17, 2014. http://ca.gov/Drought/news/ story-27.html 
California, State Water Resources Control Board. 2014. Emergency Conservation Regulations. http://www.swrcb.ca.gov/waterrights/water issues/programs/ drought/emergency regulations waterconservation.shtml

Clevenger, A. 2014. Senate Bills on C\&C lands, Klamath Basin Advance. The (Bend, Oregon) Bulletin. November 14. http://www.bendbulletin.com/localstate/2583079-151/ senate-bills-on-oc-lands-klamath-basin-advance?entryType $=0$

Colorado Water Conservation Board, Department of Natural Resources. 2005. Colorado Water for the 21st Century Act http:// cwcbweblink.state.co.us/weblink/0/doc/105662/Electronic. aspx?searchid=f7f87ad7-7a52-45c7-8b7f-2469076e69c8

Colorado Water Conservation Board, Department of Natural Resources. Drought Planning Toolbox. http://cwcb.state.co.us/technical-resources/droughtplanning-toolbox/Pages/main.aspx

Colorado Water Conservation Board. 2014. Colorado Water Plan. http://www. coloradowaterplan.org

Connell, D. 2010. Drought Past and Future: Developing an Auditing Framework for the Governance of Rivers in Federal Systems. Presentation at the International Drought Symposium, Water Science and Policy Center, University of California-Riverside, March 24. http://cnas.ucr.edu/droughtsymposium/presentations/Daniel\%20Connell.pdf

Davis-Franco, D. 2014. Drought Planning Toolbox: State Strategies for Mitigation and Adaptation. Webcast. American Planning Association. https://www. youtube.com/watch?v=WU0HLo-lIOc\&list=UUvqWCr2888S3boRqcOCc0HA

Disaster Mitigation Act of 2000. 2000. Public Law 106-390, an amendment to U.S. Code Chapter 68, Title 42.

Federal Emergency Management Agency. 2013. Local Mitigation Planning Handbook.

Firestone (Colorado), Town of. 2012. 2012 Drought Management Plan. http:// www.firestoneco.gov/DocumentCenter/View/72

Floress, K., L.S. Prokopy, and S. Broussard Allred. 2011. It's who you know: Social capital, social networks, and watershed groups. Society E Natural Resources: An International Journal 24:9, 871-886. doi: 10.1080/08941920903493926.

Fontaine, M.M., A.C. Steinemann, and M.J. Hayes. 2014. State drought programs and plans: Survey of the western United States. Natural Hazards Review 15: 95-99.

Garfin, G., G. Franco, H. Blanco, A. Comrie, P. Gonzalez, T. Piechota, R. Smyth, and R. Waskom. 2014. Chapter 20: Southwest climate change impacts in the United States. In The Third National Climate Assessment, J. M. Melillo, Terese (T.C.) Richmond, and G. W. Yohe, Eds., U.S. Global Change Research Program, 462-486. doi: 10.7930/J08G8HMN.

General Accounting Office (GAO). 1979. Federal Response to the 1976-77 Drought: What Should Be Done Next? CED-79-26. http://babel.hathitrust.org/ cgi/pt?id=uiug.30112033947851;view=1up;seq=1 
Geological Society of America (GSA). 2007. Managing drought: a roadmap for change in the United States. A Conference Report From Managing Drought and Water Scarcity in Vulnerable Environments - Creating a Roadmap for Change in the United States, held in Longmont, Colorado, September 18-20, 2006. http:// www.geosociety.org/meetings/06drought/roadmapHi.pdf

Haigh, T., L. Darby, N. Wall, and D. Bathke. 2014. Regional Drought Early Warning System Pilot in the Apalachicola-Chattahoochee-Flint Basin: Evaluation of Activities and Outcomes. National Integrated Drought Information System: Boulder, Colorado. Publication pending on drought.gov.

Hellmuth, M.E., S.J. Mason, C. Vaughan, M.K. van Aalst, and R. Choularton (eds) 2011. A Better Climate for Disaster Risk Management. New York: International Research Institute for Climate and Society (IRI), Columbia University.

Howitt, R.E., J. Medellin Azuara, D. MacEwan, J.R. Lund, and D.A. Sumner. 2014. Economic Analysis of the 2014 Drought for California Agriculture. Report, Center for Watershed Sciences, University of California, Davis, California. https:// watershed.ucdavis.edu/files/biblio/DroughtReport 23July2014 0.pdf

Huitema, D., E. Mostert, W. Egas, S. Moellenkamp, C. Pahl-Wostl, and R. Yalcin. 2009. Adaptive Water Governance: Assessing the Institutional Prescriptions of Adaptive (Co-) Management from a Governance Perspective and Defining a Research Agenda. Ecology and Society 14(1):26. http://www.ecologyandsociety. org/vol14/iss1/art26/

Innes, J.E., and D.E. Booher. 2010. Planning With Complexity: An Introduction to Collaborative Rationality for Public Policy. London and New York: Routledge, Taylor and Francis Group.

Jacobs, K.L. and J.M. Holway. 2004. Managing for sustainability in an arid climate: lessons learned from 20 years of groundwater management in Arizona, USA. Hydrogeology Journal 12:52-65. doi: 10.1007/s10040-003-0308-y.

Klamath Restoration Agreements. 2014. Wyden Introduces Bill to Implement Klamath Agreements. http://www.klamathrestoration.org/ Lovett, I. 2014. California Approves Forceful Steps Amid Drought. The New York Times, New York.

McNutt, C.A., M.J. Hayes, L.S. Darby, J.P. Verdin, and R.S. Pulwarty. 2013. Developing early warning and drought risk reduction strategies. In Drought, Risk Management and Policy, edited by Linda Courtenay Botterill and Geoff Cockfield, 151-170. Boca Raton, Florida: CRC Press.

Milly, P.C.D., J. Betancourt, M. Falkenmark, R.M. Hirsch, Z.W. Kundzewicz, D.P. Lettenmaier, and R.J. Stouffer. 2008. Stationarity is dead: Whither water management? Science 319(5863):573-574. doi: 10.1126/science.1151915.

Montgomery, C.K., ed. 2011. Introduction to Regional Planning for a Sustainable America: How Creative Programs Are Promoting Prosperity and Saving the Environment. New Brunswick, New Jersey: Rutgers University Press.

National Climatic Data Center (NCDC). 2015. Billion-Dollar Weather/Climate Disasters: Table of Events. National Oceanic and Atmospheric Administration. Accessed June 11, 2015. http://www.ncdc.noaa.gov/billions/events 
National Drought Policy Commission. 2000. Report: Preparing for Drought in the 21st Century. http://govinfo.library.unt.edu/drought/finalreport/fullreport/ pdf/reportfull.pdf

National Integrated Drought Information System (NIDIS). 2007. The National Integrated Drought Information System Implementation Plan. June. http:// drought.gov/media/imageserver/NIDIS/content/whatisnidis/NIDIS-IPFinalLune07.pdf

NIDIS. 2009. The National Integrated Drought Information System (NIDIS) Apalachicola- Chattahoochee-Flint River Basin Drought Early Warning Pilot. http://www.drought.gov/drought/regional-programs/acfrb/goals

NIDIS. 2014. National Drought Forum Summary Report and Priority Actions: Drought and U.S. Preparedness in 2013 and Beyond. http://drought.gov/drought/content/ national-drought-forum-summary-report-and-priority-actions

Overpeck, J.T. 2013. The challenge of hot droughts. Nature 503: 350-351. doi: 10.1038/503350a.

Randolph, J. and M. Bauer. 1999. Improving environmental decision-making through collaborative methods. Policy Studies Review 16:168-191.

Rittel, H.W.J. and M.M. Webber. 1973. Dilemmas in a general theory of planning. Policy Sciences 4: 155-169.

Schwab, J.C., ed. 2013. Planning and Drought. Planning Advisory Service Report No. 574. Chicago: American Planning Association.

Shandas, V. and G. Hossein Parandvash. 2010. Integrating urban form and demographics in water-demand management: an empirical case study of Portland, Oregon. Environment and Planning B: Planning and Design 37(1):112128. doi:10.1068/b35036.

State of California, Executive Department. 2015. Executive Order B-29-15. http:// www.waterboards.ca.gov/waterrights/water_issues/programs/drought/ docs/040115_executive_order.pdf

Svoboda, M., K.H. Smith, M. Widhalm, M. Shafer, C. Knutson, M. Spinar, D. Woudenberg, M. Sittler, R. McPherson and H. Lazrus. 2011. Drought Ready Communities: A Guide to Community Drought Preparedness. http://drought. unl.edu/portals/0/docs/DRC Guide.pdf

United Nations International Strategy for Disaster Reduction (UNISDR). 2013. From Shared Risk to Shared Value-The Business Case for Disaster Risk Reduction. Global Assessment Report on Disaster Risk Reduction. Geneva, Switzerland: United Nations Office for Disaster Risk Reduction. http://www. preventionweb.net/english/hyogo/gar/2013/en/gar-pdf/GAR13 infographic min.pdf

U.S. Bureau of Reclamation (USBR). 2012. Colorado River Basin Water Supply and Demand Study: Executive Summary. http://www.usbr.gov/lc/region/ programs/crbstudy/finalreport/Executive\%20Summary/CRBS Executive Summary FINAL.pdf

Weiser, M. 2013. State Urges Steps to Prepare for Drought in 2014. Sacramento Bee, Sept. 6. 
Whitney, Gene. 2013. Scientists and drought policy: A US insider's perspective. In Drought, Risk Management and Policy, edited by Linda Courtenay Botterill and Geoff Cockfield, 71-85. Boca Raton, Florida: CRC Press.

Wilhite, D.A. 1990. Planning for Drought: A Process for State Government. IDIC Technical Report Series 90-1. International Drought Information Center, University of Nebraska-Lincoln.

Wilhite, D.A. 1991. Drought planning and state government: Current status. Bulletin of the American Meteorological Society 72(10):1531-1536.

Wilhite, D.A., M.J. Hayes, and C.L. Knutson. 2005. Drought preparedness planning: Building institutional capacity. In Drought and Water Crises: Science, Technology and Management Issues, edited by Donald A. Wilhite, 93-135. Boca Raton, Florida: CRC Press.

Wilhite, D.A. and R.S. Pulwarty. 2005. Drought and water crises: Lessons learned and the road ahead. In Drought and Water Crises: Science, Technology, and Management Issues, edited by Donald A. Wilhite, 389-398. Boca Raton, Florida: CRC Press. 